\title{
Meiosis and Development of the Embryo Sac in Gunnera insignis (Oersted) D.C. (Halorhagaceae)
}

\section{Niilo Virkki \\ INTRODUCTION AND REVIEW OF LITERATURE}

The halorhagacean genus Gunnera has an interesting distribution in mountainous regions of Africa, Southeast Asia, Tasmania, New Zealand, and South and Central America. In the Costa Rican mountains, where the writer had an opportunity to roam in 1961, three species are reported to occur: Gunnera insignis (Oersted) D.C., G. talamancana Weber and Mora; and as an uncertain species, $G$. wendlandii Reinke (17, pp. 25-6) ${ }^{2}$. Gunnera insignis is an especially large plant, which, under proper conditions, develops leaves approximately $2 \mathrm{~m}$. in diameter (fig. 1 ). The red inflorescences are so big that the local mountain people use them as Christmas trees. The plant possesses a high ornamental value, and it would be worthwhile to try it out for this purpose.

The chromosome relations of the genus Gunnera are practically unknown. Aside from some quite unreliable early observations, the count made by Winge (18) seems to be the only report. He gave 12 as the reduced number for Gunnera chilensis Lam. Darlington and Wylie (2) pronounced this questionable.

More attention has been paid to the structure and development of the embryo sac in Gunnera. This is partly because of the rarity of such embryo sacs. No recent work has been done, however, all original papers dealing with the embryogenesis of Gunnera being over 50 years old.

The structure of the embryo sac is subject to much variation. The majority of the sacs are monosporic in origin; in other words, they are derived from only one of the four megaspores produced by the meiotic divisions. This early stage of development parallels that of animal oogenesis, where only one of the four cells produced survives and forms the egg. In the plants, however, the variation exceeds this parallelism: di-, tri-, and tetrasporic embryo sacs occur.

Further division of embryo sacs into types is based on the number of the nuclei in the ripe sac. Thus Maheshwari (12) mentioned 10 types, most of which can be divided into subtypes. Fagerlind ( 8 ) also took into account

${ }^{1}$ Assistant Cytogeneticist, Agricultural Experiment Station, University of Puerto Rico, Río Piedras, P.R.

${ }^{2}$ Italic numbers in parentheses refer to Literature Cited, pp. 267-8. 
polarity relations, fusion, and failure of division of nuclei, as well as the number of synchronous divisions needed for the final organization of the embryo sac. Only the tetrasporic embryo saces are thus divided into 10 subtypes. Variation within the subtypes is further encountered, and there can

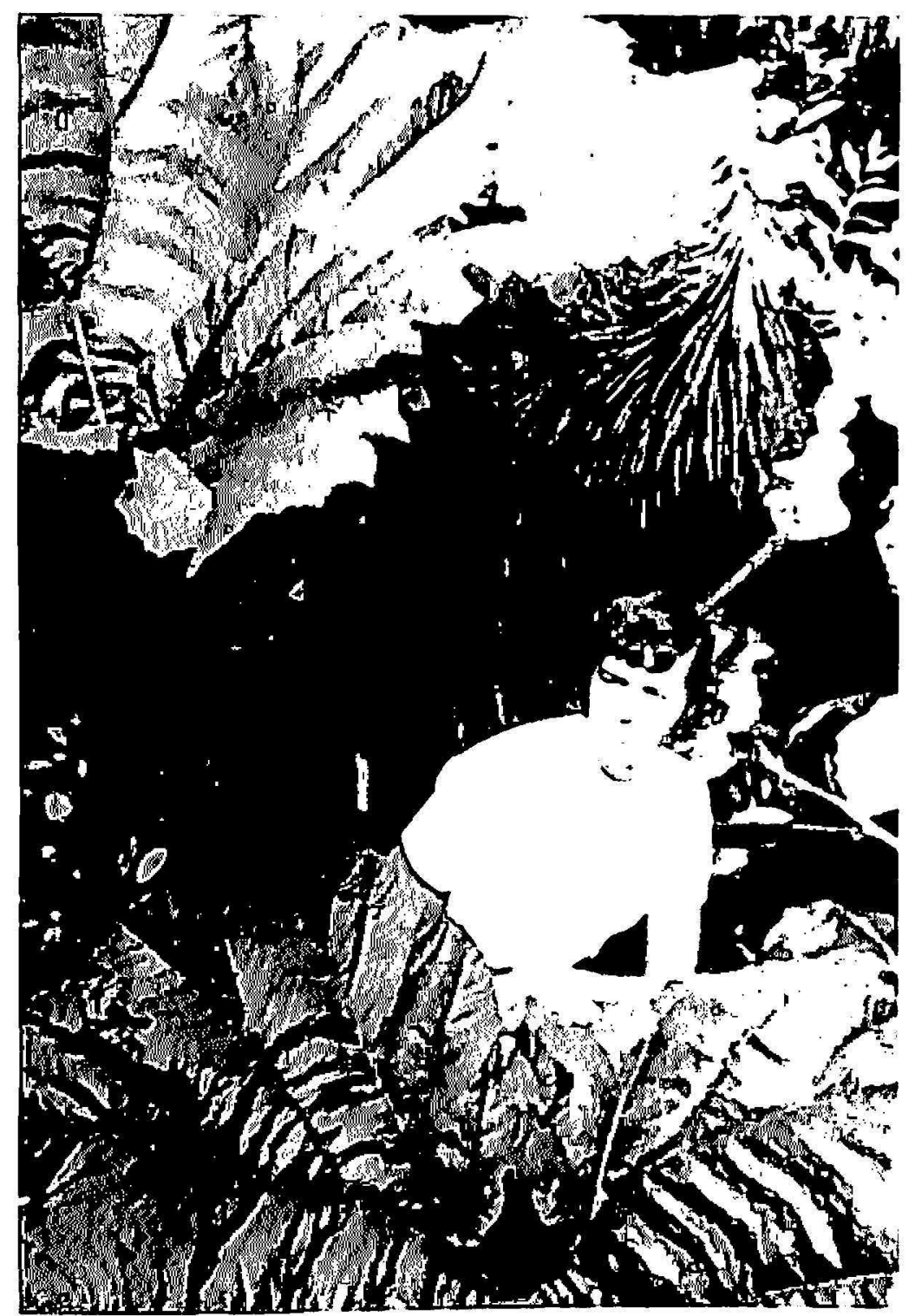

FIG. 1.-Close-up view of Gunnera insignis, demonstrating dimensions of a wellgrown plant. This is one of the plants which provided material for the present study.

be variation in the structure and development of the embryo sace, even in one and the same species, as in Peperomia pellucida Kunth (6).

Fagerling (8) mentioned two mechanical factors which seem to contribute to the final structure of an embryo sac. Thus the number of the polar nuclei is the same as the number of cell groups formed within the sac. Furthermore, the shape of the anlage of the embryo sac determines the 
number and location of the cell groups (the polarity). Narrow, elongate embryo sacs are bipolar, having only the micropylar and the chalazal cell groups, and two polar nuclei. In an opposite case, where the embryo sac is round, as in Peperomia pellucida (6), the grouping of cells is more liberate, and a multipolar structure with many polar cells arises. Gunnera is regarded as a mediating example (8). Its embryo sac is pyramidlike. The broad chalazal end shows multipolarity and produces many polar nuclei. On the contrary, the micropylar cell group with the egg cell is trapped in the narrow apex and remains unipolar and produces only one polar nucleus.

The embryo sac of Gunnera has been studied in three species: G. hamillonii T. Kirk (16), G. chilensis Lam. $(10,19,16)$, and G. macrophylla Blume $(3,4,14)$. The first-mentioned species represents New Zealandian flora, the second is South American, and the last Malayan. A tetrasporic embryo sac was reported in all cases, although opinions differed somewhat on the details of its development. An essential characteristic is that all four megaspores survive and undergo two successive waves of mitoses. The mature sac is consequently formed by 16 cells. The two synergids tend to disintegrate, and the central group of 7 polar cells fuses to form a giant polyploid central nucleus. The number of antipodal cells is 6 .

\section{MATERIAL AND METHODS}

Material of Gunnera insignis was collected by the writer near Empalme, about 2,500 $\mathrm{m}$. above sea level, in the Cordillera de Talamanca of Costa Rica, in February 1961. Small portions of the inflorescences were immersed in 1:3 acetic alcohol ${ }^{3}$ at the place of collection. In lack of laboratory facilities the material remained in the fixative until March of the same year, when it was partly stained with acetic orceine and partly processed for paraffine sectioning.

Acetic orceine squashes were made to check the meiosis in the pollen mother cells. As the anthers are thick-walled and hard, they resist squashing, despite heating in the acetic stain. They were tapped with a glass rod on an albuminized slide, covered, heated again, and squashed with a simple "cell-press" developed by Dr. V. Sorsa, Institute of Genetics, University of Helsinki, Finland, which applies a pressure of 150 to $250 \mathrm{~kg} . / \mathrm{cm} .{ }^{2}$ on the coverslip. The major part of the best material, consisting of loose PMC, is squeczed out from below the coverslip. It can be collected easily from the borders of the coverslip with a small scalpel, and smeared on another albuminized slide. The smear is then squashed again. Both squashes are made permanent with usual dehydrating techniques. The smear-squashes provide the best preparations with sufficient flattening of the PMC.

${ }^{3}$ A mixture of acetic acid and ethyl alcohol. 
For mitotic chromosomes, nucelli were operated out of the pistils, heated in acetic orceine, and squashed on albuminized slides with the cell-press.

For the female meiosis and structure of the embryo sac, material was refixed in CRAF for 1 day, and transferred to paraffin through the usual ascending butanol series. Slides were prepared with the sectioning technique, using ribbon thickness of 10 to $15 \mu$. A hydrolysis of 22 minutes was made in 1-normal $\mathrm{HCl}$ at $60^{\circ} \mathrm{C}$., and thereafter the sections were stained with leuco basic fuchsin. Propionic carmine and acetic haematoxylin, mentioned by Darlington and La Cour (1), also were used in many cases as stains.

The Ortholux microscope of Leitz, provided with a 1.32, 100x oil-immersion objective, was used for the study and the pictures. Drawings were made with camera lucida for a final magnification of $1280 x$. Microphotographs were taken with the camera Makam, of Leitz, using $12^{\circ}$ DIN Silbereosin glass plates of Perutz. Final magnification of the microphotographs is $1300 x$.

\section{OBSERVATIONS}

\section{MITOTIC CHROMOSOME COMPLEMENT}

In this species, mitotic divisions are quite common in the nucellus tissue just before, during, and after the MMC meiosis; $3-4$ mitotic metaphases and anaphases per nucellus are a very usual case. Thus nucellus tissue provided reliable chromosome counts, despite the lack of adequate pretreatment for such purposes. The diploid number consists of 34 chromosomes of very different size. In anaphase groups they appear rod-shaped, which suggests acrocentry in all of them (figs. 2,A, and 3,A).

\section{MEIOSIS IN POLLEN MOTHER CELLS}

Early prophase stages leptotene, pachytene, and sometimes even zygotene, are definable, but do not suffice for analyzing single chromosomes. No nucleolus was observed, nor conspicuous heterochromasy.

From middiplotene on, the 17 bivalents are free and compact enough to be observed individually. The chiasma frequency is not high. Two chiasmata per bivalent is the highest number scen. Smaller hivalents have one single chiasma (figs. 2, B and $3, \mathrm{~B}-\mathrm{F}$ ). In four cases, the smallest two chromosomes remained as univalents.

A remarkable phenomenon in the late prophase is the low rate of chiasma terminalization. There is really very little change of the position of chiasmata betwcen middiplotene and first metaphase. In fully formed metaphase plates there are always unterminalized chiasmata recognizable (figs. 3,E-F). 


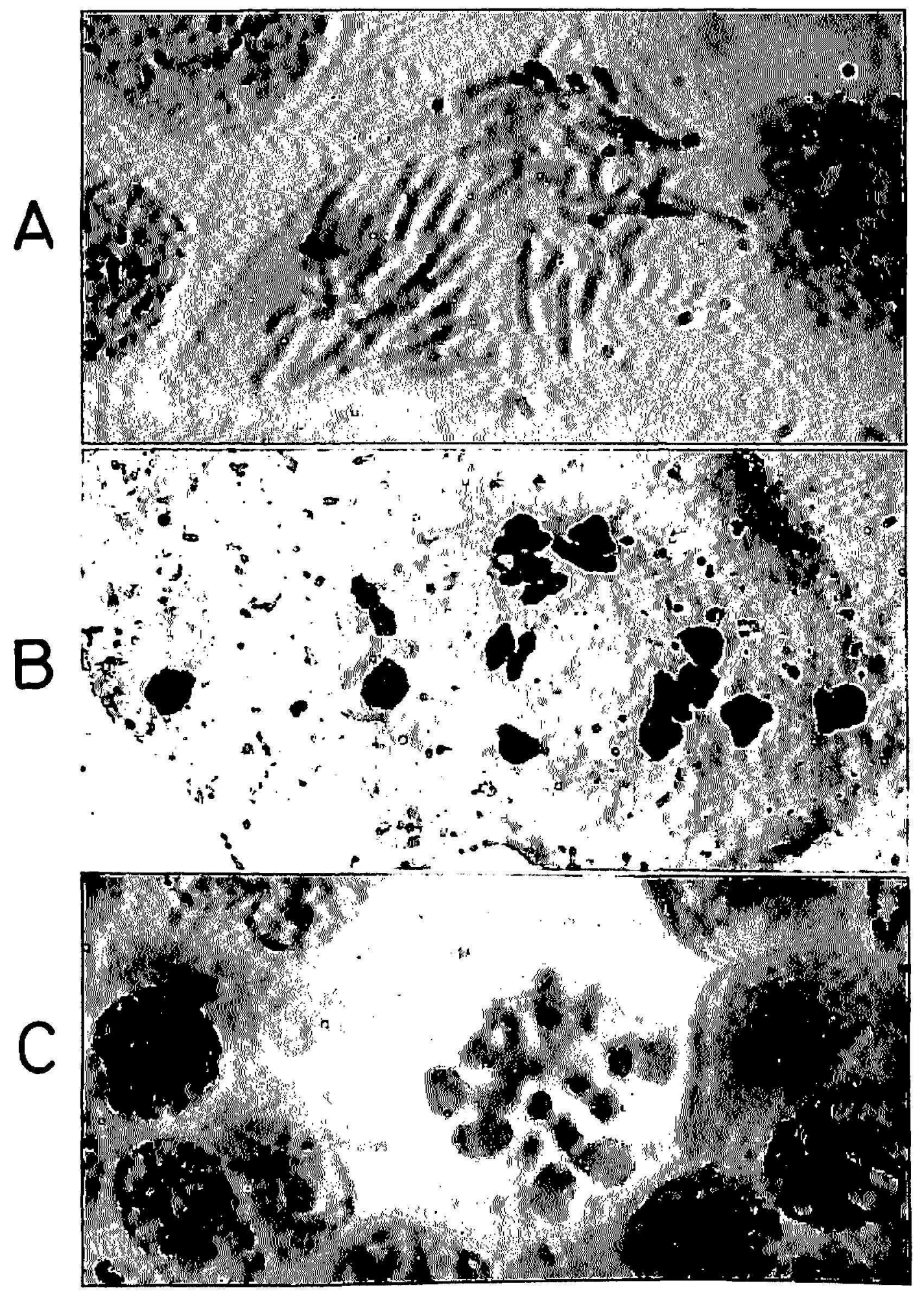

Fig. 2.-The chromosomes of Gunnera insignis; compare with figs. 3,A and D, and $4, A: A$, Nucellus cell in anaphase. $2 n=34 ; 1$, first meiotic prometaphase of PMC; 17 bivalents; C, polar view of the first meiotic metaphase of MMC; 17 bivalents, proximally localized chiasmata. Centromere regions denser colored. Stains: Acetic orceine in $\Lambda$ and $B$, propionic carmine in $C$. 


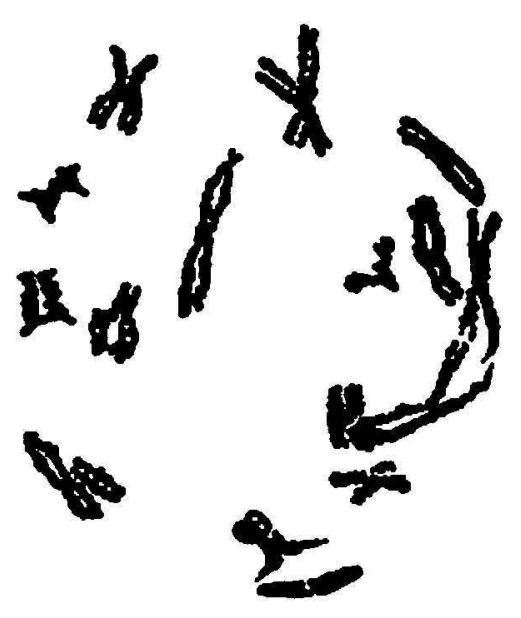

B

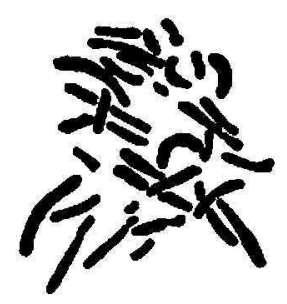

A
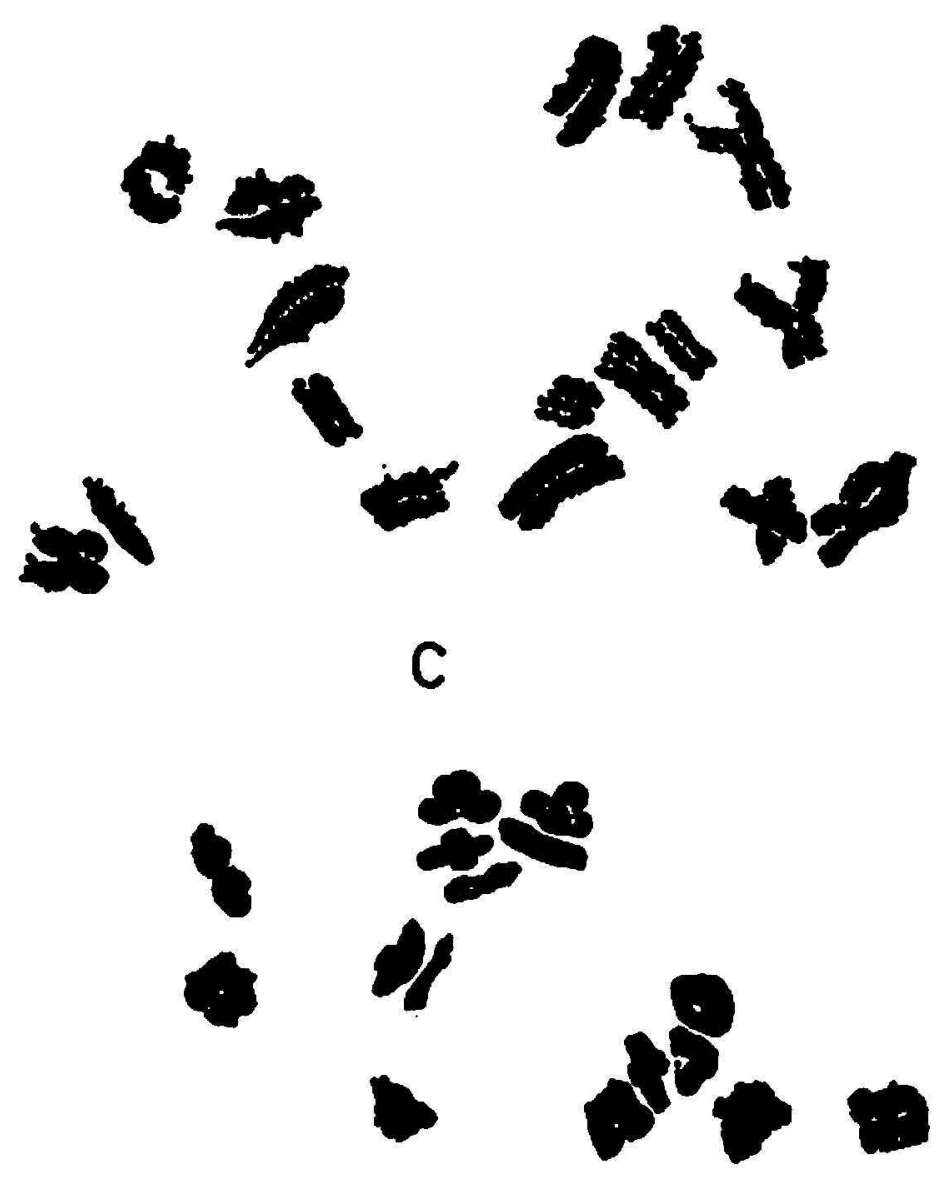

D

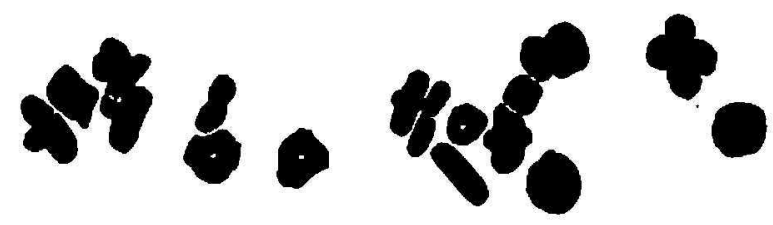

E

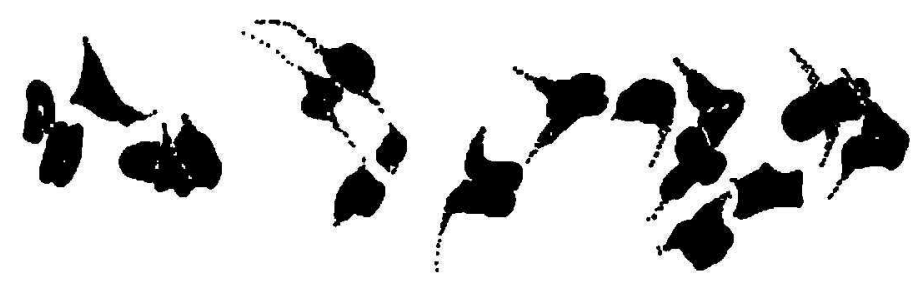

F

Fig. 3.-Somatic chromosome number, and development of bivalents in the meiosis of PMC: A, One anaphasic group of a dividing nucellus cell, showing 34 acrocentric chromosomes. B, Young diakinesis. C, Diakinesis. D, First prometaphase. E, First metaphase; note the incomplete terminalization of chiasmata in this late stage. F, Late first metaphase showing position of centromere and localization of chiasmata in many bivalents. Stain: Acetic orceine. Squash preparations. 
There may be localization of chiasmata in many bivalents. This is to be expected, especially in 4 or 5 bigger or middle-sized bivalents which frequently show complete lack of chiasma movement up to the plate of the first metaphase. First telophase leads to a completely interphasic nucleus.

The second meiotic division is typically equational and shows 17 chromosomes. Both divisions were free of anomalies, except the few cases of univalents mentioned above.

Ripe pollen grains are trilobed as described already by Samuels (14) in Gunnera macrophylla.

\section{MEIOSIS IN MEGASPORE MOTHER CELLS}

Both the male and the female meiosis occurred at approximately the same time. Thus sections showing divisions of MMC may show meiotic metaphases of PMC as well.

The nucellus of Gunnera insignis has turned around near $180^{\circ}$, and may be called therefore anatropous (12). Prophasic MMC show classic stages of leptotene and pachytene. There is probably no terminalization of chiasmata at all. The bivalents of the first metaphase of meiosis are more compact than those in the PMC, but show well the localization of chiasmata (figs. 4,A-C, and 2,C).

The first division occurs along the longitudinal axis of the only slightly elongated MMC, and leads to the binucleate stage. In the plates of the first anaphase the chromosomes show a constriction or an unstained gap at their middle part (fig. 4,D). Although it undoubtedly marks the centromere, the chromosomes cannot be considered mediocentric, especially because mitotic divisions suggest acrocentry. This is just how acrocentric chromosomes look if their chromatids are spread far from one another, as is common in the first anaphase of meiosis. No cell wall is formed between the two daughter nuclei (fig. 4,E).

The second division occurs more or less obliquely to the length axis (fig. 4,F), leading to four megaspore nuclei, two of which remain in the ends and two at the equator of the common cytoplasmic body or coenomegaspore (coenomacrospore). The two equatorial nuclei tend to migrate towards the chalazal end.

\section{DEVELOPMENT AND BTRUCTURE OF FMBRYO SAC}

The embryo sac of Gunnera insignis is tetrasporic. First signs of its development after meiosis are the conspicuous growth and vacuolization of the coenomegaspore. There may be some continuation in lowering-down of the two equatorial megaspore nuclei, (fig. 5,A), but, on the other hand, cases of far-gone vacuolization have been seen, where these nuclei have remained at the equator (fig. 5,B). There is thus no regular $1+3$ grouping 


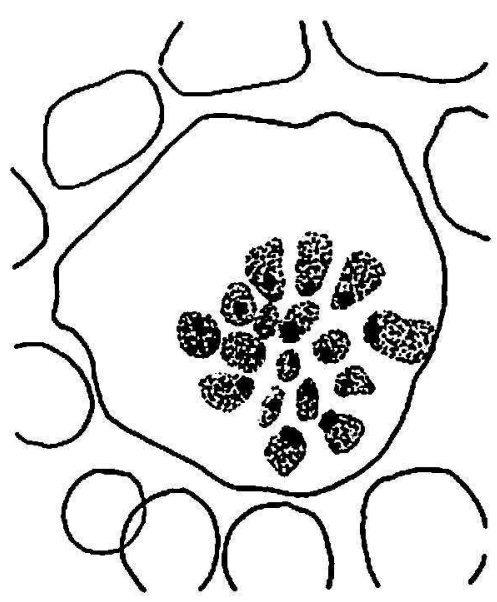

A

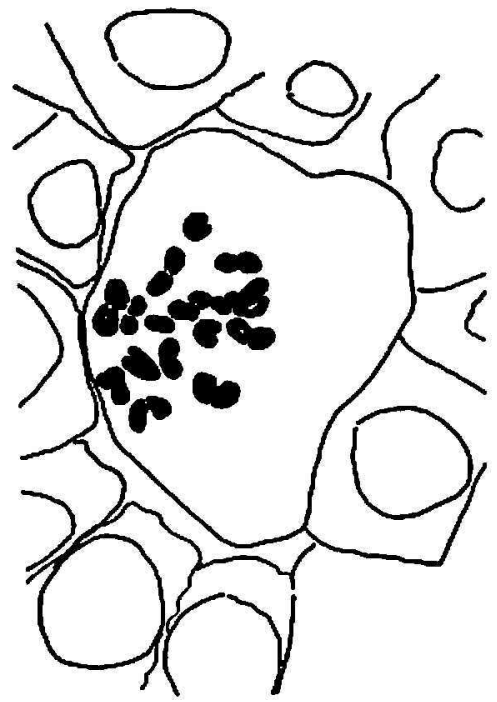

D

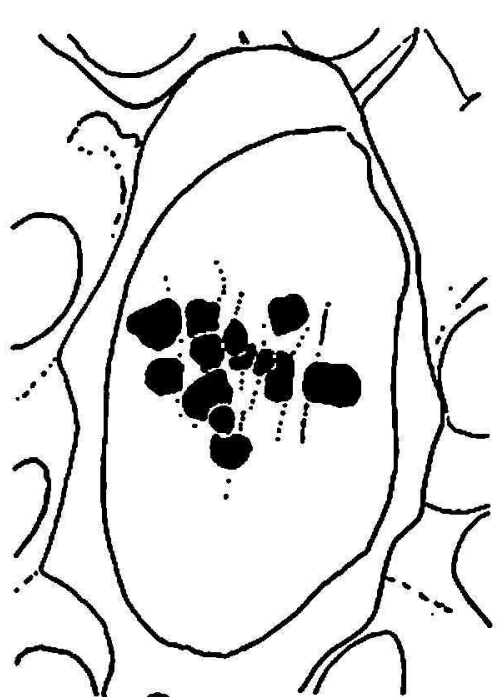

B

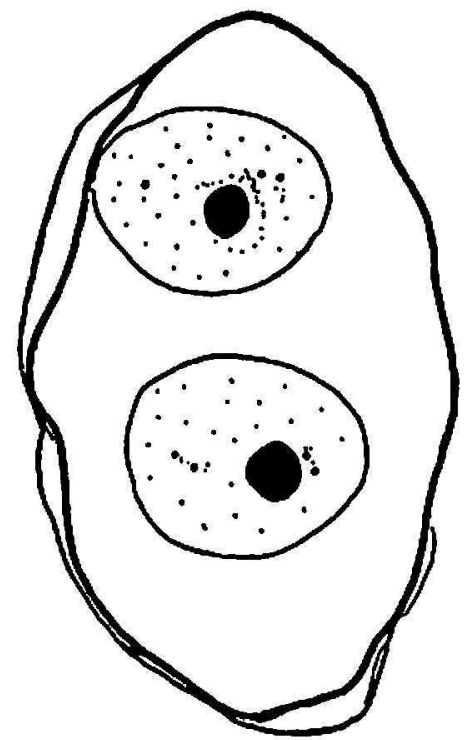

E

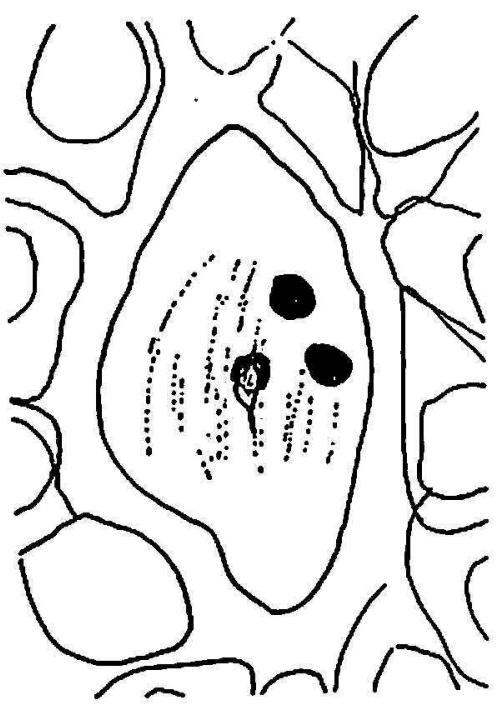

C

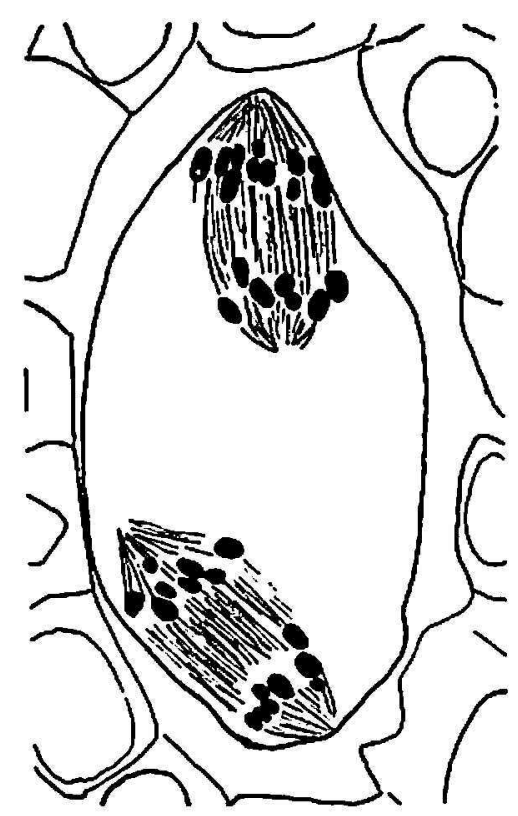

$F$

Frg. 4.-Meiosis in the MMC: A, First metaphase. B, C, First metaphase, profile views of a cell sectioned in two; note position of centromeres and localization of chiasmata. D, First anaphase, 1 of the 2 chromosome groups; separated chromatids cause a metacentriclike appearance of the chromosomes. E, Binucleate stage after the first division. F, Second meiotic anaphase. Stains: Leuco basic fuchsin in D, propionic carmine in others. Sectioned preparations.

of the coenomegaspore nuclei, as there was, according to the illustrations of Samuels (14), in Gunnera macrophylla.

Unfortunately, the present material does not contain embryo-sac mitoses, nor the 8-nucleate stage. The series continues with a recently formed 16- 

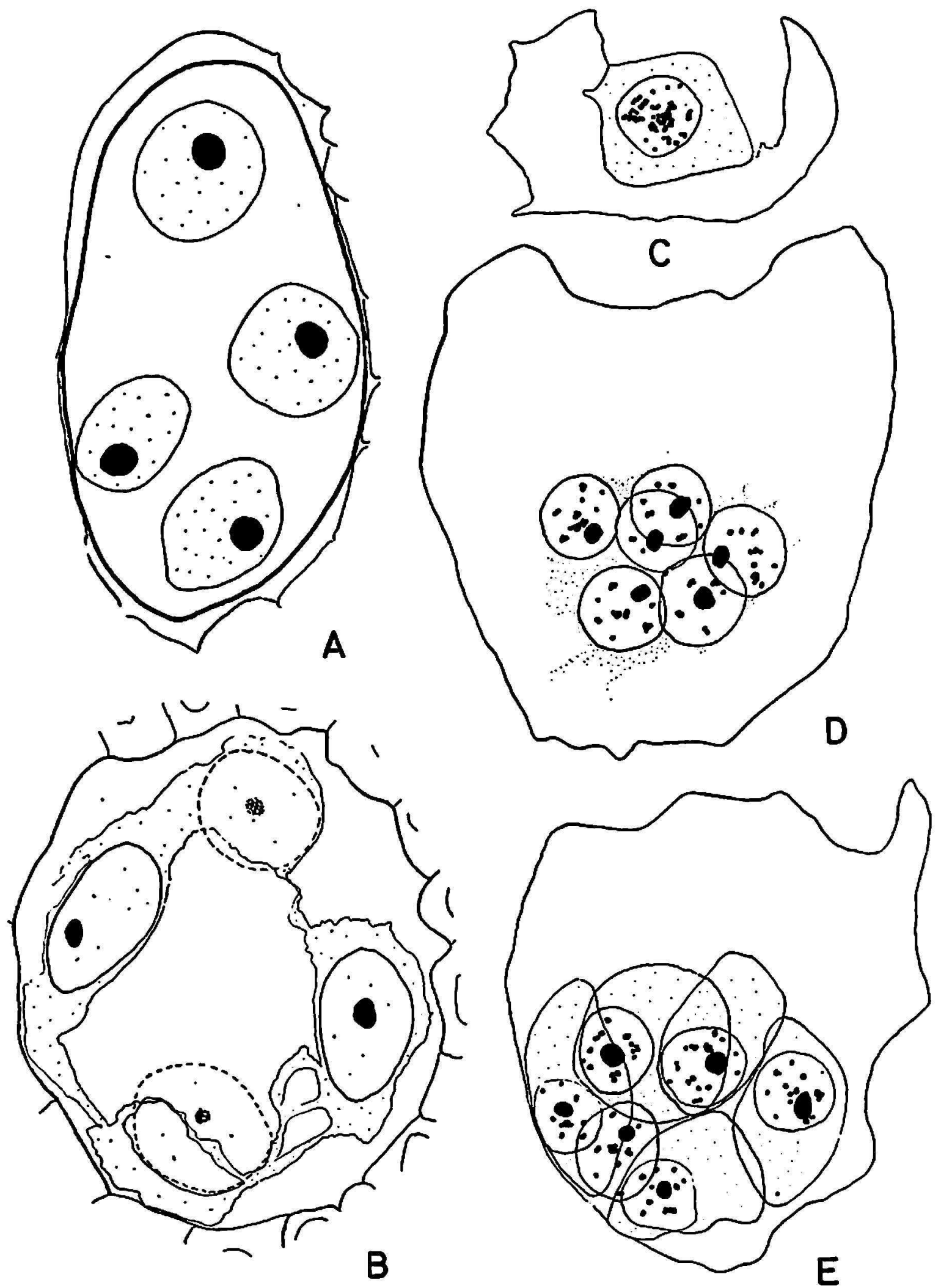

Fig. 5.-Development of embryo sac: A, Quadrinucleate stage (coenomegaspore) after the meiotic divisions. $B$, The same, but a later stage; note the central vacuolization. C, D, and E, Three successive sections of a premature embryo sac: C, Micropylar section showing the egg cell; $D$, middle section showing 6 polar nuclei surrounded by syncytious cytoplasm; $\mathrm{E}$, chalazal section showing 5 antipodal cells and 1 of the polar nuclei which remained unusually low; one of the antipodal cells is lacking from this section. Stains: Acetic orceine in A and B, acetic haematoxylin in others. Sectioned preparations. 
nucleate stage. At this stage, the embryo sac is roughly shuttle- or pyramidshaped. In the micropylar corner lies the solitary egg cell. The synergids have apparently degenerated. A group of seven polar nuclei lies at the middle of the sac, surrounded by residual cytoplasm. In the chalazal end there are six antipodal cells with well-defined individual cell bodies (fig. 5,C-E).

The fully organized embryo sac has a rough pyramidal shape (fig. 6,A).

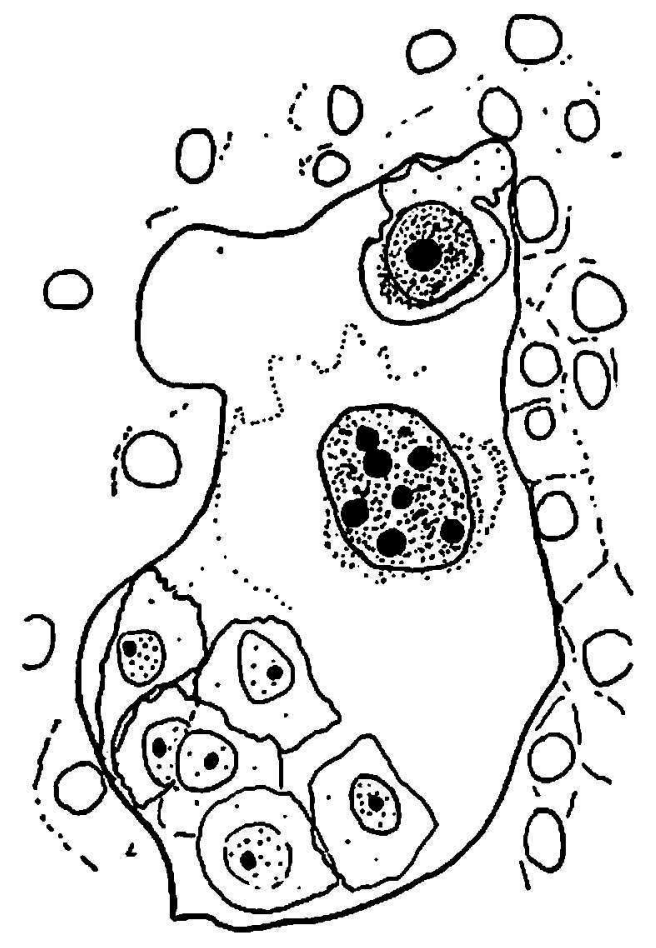

A

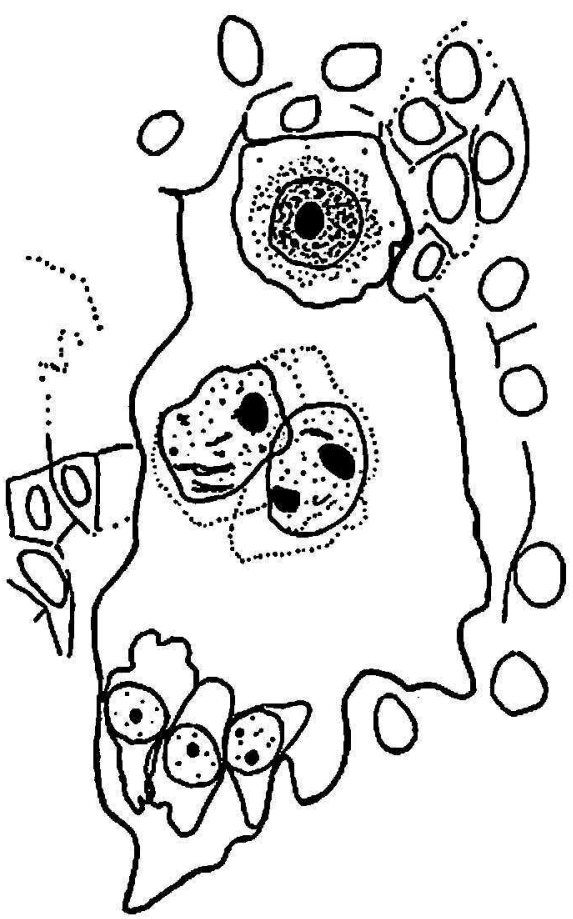

B

Fig. 6.-Structure of the mature embryo sac: A, Normal case, showing 6 antipodal cclls, central giant nucleus with 7 nucleoli, and egg cell in the micropylar apex. B, A case with 2 central nuclei; 3 antipodal cells cut away. Stain: Acetic orceine. Sectioned preparations. Magnification only $500 \times$.

The big, plasmous egg cell, and the degenerating six antipodal cells can be individually counted. The central group of polar cells has formed a giant fusion nucleus, where seven nucleoli can still be counted sometimes. In two embryo sacs two smaller fusion nuclei were encountered instead of one large (fig. 6,B).

\section{DISCUSSION}

\section{CHROMOSOME RELATIONS}

Both Modilewski (13) and Winge (18) reported 12 as the probable reduced chromosome number for Gunnera chilensis, and Samuels (14) gave 
the same number for $G$. macrophylla. Winge counted the number in prophases of pollen-grain mitoses, whereas Modilewski and Samuels observed embryo-sac divisions from sectioned material. All these data are quite unreliable owing to unsuitable stages and bypassing observations. It remains therefore for the future workers to state whether that number really occurs among Gunnera; at the present, it cannot be taken into consideration.

The counts $2 n=34$ and $n=17$ made here in Gunnera insignis set down $x=17$ for Gunnera. This is quite a high number as a basic chromosome number. We do not have sufficient data to understand its origin. It could be a derivative of $x=7$, especially because that number occurs in the family Halorhagaceae, in several Myriophyllum species $(2,11,9)$. The somatic number 34 could then have arisen through the $5 x=35$ condition.

The most remarkable phenomenon of the meiosis of Gunnera insignis is the strict localization of chiasmata to the proximal (procentric) end of each bivalent in the first metaphase of MMC. There are no comparable data available from Halorhagaceae. The case resembles cases like Fritillaria pallidiflora (1, plate XI). Provided a chiasma means occurred crossing over, the recombination pattern is much simplified by restriction of the crossing over to the vicinity of the centromere. Thus linkage groups are maintained which practically have the length of a whole chromosome arm. As the chromosomes of Gunnera insignis are acrocentric, this means that the genetical effects of the localization come near to those of a nonchiasmate meiosis. Additional chiasmata in bigger bivalents sometimes counteract this simplification of the recombination.

The relations seem a little different in the PMC meiosis. Proximal localization of chiasmata is encountered prevailing in some medium-sized and big bivalents. Apparently terminalization of chiasmata occurs in most brivalents, although at a very slow rate. It was not possible to see whether the initial location was close to the centromere. The chances are that localization of crossing over exists here also, but is not detectable, owing to the moving of chiasmata.

As the mean frequency of chiasmata also remains below two per bivalent in both PMC and MMC meiosis, the case gives an impression of a somewhat conservative cytology, where genic recombinations are not very readily to be experimented with.

The doubts of Schnegg (16) and Modilewski (13) about the possibility of apomixis in Gunnera do not receive any support from the cytology of the meiosis of $G$. insignis. A curiosity worth mentioning in this connexion is that no seed were encountered in the plants in Talamanca, although old inflorescences were seen. 


\section{EMBRYO SAC}

There is no essential difference in the development and structure of the embryo sac of Gunnera insignis as compared with data available from other Gunnera species. The simplified description given by Modilewski (13) for Gunnera chilensis may serve for other species as well. According to him the main lines of embryo-sac development in that species are as follows: The nucleus of the macrospore mother cell divides and gives rise first to 2 and then, after another division, to 4 nuclei which are not separated by new cell walls. One of the nuclei remains in the micropylar corner and 2 equatorially located nuclei migrate to the chalazal end to accompany the nucleus situated there. A central vacuole forms. Two synchronous divisions of all nuclei follow, resulting in 4 nuclei in the micropylar end, and 12 nuclei in the chalazal end. One of the micropylar nuclei forms the egg cell; 2 nuclei, the synergids, degenerate, and 1 , a polar nucleus, migrates to the center of the sac. Of the 12 chalazal nuclei the 6 uppermost ones also migrate to the center, where all 7 nuclei fuse together forming the giant polyploid polar nucleus. The 6 cells remaining in the chalazal end form the antipods.

Modilewski erroneously thought that the MMC started the embryo-sac divisions immediately. The first two divisions are the first and second meiotic divisions, so that there remains no doubt of the nature of the four nuclei formed: they are true megaspores. Such a syncytial polynucleate megaspore is called coenomegaspore by Fagerlind (8). Only the two following waves of synchronous mitoses can be regarded as embryo-sac divisions. This is why Fagerlind (8) called this type of embryo sac 2-phasic.

At first sight the embryo sac of Gunnera looks bipolar. This was also the opinion of the early students of the Gunnera embryogenesis. However, Ernst (4) and Samuels (14) had already observed the presence of three groups of two nuclei in the chalazal end of the sac. Fagerlind (8), convinced by his vast experience with angiosperm embryology, was of the opinion that the number of polar nuclei always corresponded to the cell groups formed. He thought that each of the six chalazal nuclei of Gunnera embryo sac represented a "group," which produced one polar nucleus in the last synchronous mitosis. If this interpretation did not hold, Gunnera would be one of the very few cases violating his "polarity rule."

Thus, according to the terminology of Fagerlind, the embryo sac of the Gunnera species is 16-nucleate, 4-sporic, 2-phasic, and multipolar. It is also called the Peperomia type according to the genus where it was first encountered, or even the Gunnera form of the Peperomia type, to emphasize the different shape and organization of the Gunnera sac (15).

The details in which the embryo sac of Gunnera insignis differs from that of the earlier-studied Gunnera species, are probably insignificant. The 
shape of the mature sac is said to be pyramidlike (8). It does not appear so from the illustrations of the earlier authors, but is confirmed here in $G$. insignis. The synergids were not seen in $G$. insignis, and may degenerate very early in this species.

It is interesting to note that, in two sacs of $G$. insignis, there was a pair of smaller giant nuclei in the center instead of a single large one. This may indicate that the repolarization of the nuclei is sometimes incomplete. The basal groups of the nuclei formed in the first phase have probably been so far from one another that polar nuclei formed in the second phase fused to form two nuclei apart from one another. Sometimes the antipodal body of Gunnera has also been encountered bipartite (3). It seems most probable that the two equatorial nuclei of the coenomegaspore are principally responsible for these phenomena. If they do not descend much from their original position, the groups $(4+4)$ of their daughter nuclei remain far from one another. Direct observations show that the original tetrapolarity of the coenomegaspore of $G$. insignis can really persist still when the central vacuolization has proceeded far and the embryo-sac anlage grown considerably. In general, the migration of the two equatorial nuclei of the coenomegaspore of $G$. insignis towards the chalazal end is neither rapid nor complete. No enlarging of the micropylar cell was seen either.

There are five families: Piperaceac, Tamaricaceae, Peneaceae, Limnanthaceae, and Plumbaginaceae, where the tetrasporic embryo sac occurs, as a rule, and in certain others some genera only show it (8). Halorhagaceae is one of the latter.

These relations suggest a polyphyletic origin rather than an old, primitive stage of development. Fagerlind $(5,6)$ held it most probable that the tetrasporic embryo sac was a derivative of the monosporic, sometimes perhaps of the bisporic sac-type. Occurrence of tetrasporic gametophyte in gymnosperms (7) suggests, however, the possibility that some lower angiosperms may have a tetrasporic embryo sac of primitive origin.

As pointed out by Fagerlind (8), the systematic value of the tetrasporic embryo sac is obvious, but restricted to cases where it supports views obtained from other systematically important characteristics. In the Halorhagaceae particularly, it together with the chromosome number, would support the establishment of a separate family Gunneraceae.

\section{SUMMARY}

Gunnera insignis (Oersted) D.C. is a halorhagacean plant from the mountains of Costa Rica, a giant species which can be considered as a potential ornamental. The chromosome relations of the whole genus Gunnera have been practically unknown. The diploid chromosome complement of Gunnera insignis consists of 34 acrocentric chromosomes of quite differ- 
ent size. Both PMC and MMC meiosis are normal and vigorous, showing 17 bivalents in the first division. Absolute procentric localization of the first (or only) chiasma occurs in MMC. In PMC, the same tendency is seen in a couple of big bivalents. The rate of terminalization of chiasmata in the remaining PMC bivalents is low.

The mature embryo sac of Gunnera insignis is tetrasporic, 16-nucleate, 2-phasic, and multipolar. It consists of an egg cell, a giant polyploid nucleus formed by fusion of 7 polar nuclei, and 6 antipodal cells. In exceptional cases 2 smaller fusion nuclei may occur instead of 1 large. This is considered a sign of an incomplete repolarization of the embryo sac nuclei.

\section{RESUMEN}

Gunnera insignis (Oersted) D.C. es una planta de gràn tamaño de Costa Rica con valor potencial como planta ornamental. Las relaciones cromosómicas en el género Gunnera eran prácticamente desconocidas. El complemento cromosómico diploide se compone de 34 cromosomas acrocéntricos de tamaño bastante diferente. El proceso meiótico es normal y vigoroso, tanto en las PMC, así como también en las MMC. Aparecen 17 bivalentes en la primera división. La localización procéntrica absoluta de la primera (o única) quiasma ocurre en las MMC. La misma tendencia se nota en algunos más grandes bivalentes de las PMC. El curso de la terminalización de los quiasmas en los demás bivalentes de las PMC es lento.

El saco embriónico maduro de $G$. insignis es tetraespórico, 16-nuclear, 2-fásico y multipolar; tiene una célula huevo, un núcleo gigante poliploideo formado por la fusión de 7 núcleos polares, y 6 células antipodales. Excepcionalmente, 2 núcleos de fusión más pequeños ocurren en lugar de 1 grande. Esto se considera como una señal de la repolarización incompleta de los núcleos del saco embriónico.

\section{LITERATURE CITED}

1. Darlington, C. D., and La Cour, L. F., The Handling of Chromosomes, pp. 248, Allen and Unwin, London, England, 1960.

2. Darlington, C. D., and Wylie, A. P., Chromosome Atlas of Flowering Plants, pp. 519, Macmillan Co., New York, N. Y., 1956.

3. Ernst, A., Ergebnisse neurer Untersuchungen über den Embryosack der Angiospermen, Verh. Schweiz. Naturforsch. Ges. 91 230-63, 1908.

4. - Zur Phylogenie des Embryosackes der Angiospermen, Ber. Deutsch. Bot. Ges. 26 A 419-38, 1908.

5. Fagerlind, F., Wo kommen tetrasporische durch drei Teilungsschritte vollentwickelte Embryosäcke unter den Angiospermen vor? Bot. Notiser 1938, 462-98, 1938.

6. - Die Entwicklung des Embryosackes bei Peperomia pellucida Kunth, Ark. $f$. Botan. 29 A 1-15, 1939.

7. - Bau und Entwicklung der Gnelum-Gametofyten, $K$. Svenska Vetenskapsakad. Handl. 19 1-55, 1941. 
8. - Der tetrasporische Angiospermen-Embryosack und dessen Bedeutung für das Verständnis der Entwicklungsmechanik und Phylogenie des Embryosacks, Ark. f. Botan. 31 A 1-71, 1944.

9. Jørgensen, C. A. and Sørensen, Th. and Westergaard, M., The Flowering Plants of Greenland: A Taxonomical and Cytological Survey, Biol.Skr. Dansk Vidensk. Selsk. 9 1-172, 1958.

10. Kellermann, W. A., Die Entwicklungsgeschichte der Blüte von Gunnera chilensis Lam. Dissertation, Zürich, Switzerland, 1881.

11. Löve, A., and Löve, D., Cytotaxonomical Conspectus of Icelandic Flora, Acta Hort. Gotob. 20 65-290, 1956.

12. Maheshwari, P., An Introduction to the Embryology of Angiosperms, McGrawHill, New York-Toronto-London, England, pp. 453, 1950.

13. Modilewski, J., Zur Embryobildung von Gunnera chilensis, Ber. Deutsch. Bot. Ges. 26 A 550-6, 1908.

14. Samuels, J. A., Etudes sur le développement du sac embryonnaire et sur la fécondation du Gunnera macrophylla Bl. Arch. f. Zellforsch. 8 52-120, 1912.

15. Schnarf, K., Contemporary Understanding of Embryo Sac Development Among Angiosperms, Bot. Rev. 2 565-85, 1936.

16. Schnegg, H., Beiträge zur Kenntnis der Gattung Gunnera, Flora 60 161-208, 1902.

17. Weber, H., Los Páramos de Costa Rica y su Concatenación Fitogeográfica con los Andes Suramericanos, Publ. Instil. Geogr. de Costa Rica, pp. 67, San José, Costa Rica, 1959.

18. Winge, $\emptyset$., Studier over Planterigets Chromosomtal og Chromosomernes Betydning, Meddel. Carlsberg Lab. 13 127-267, 1917. 